\author{
Elvira Küün \\ Narva College of Tartu University, Estonia
}

\title{
PECULIARITIES OF TEACHING AND LEARNING OF NEW IMMIGRANT PUPILS: ESTONIAN CASE
}

Summary. Estonia has been part of the European Union since 2004. Concerning that, it is very important for Estonia as a Member State of the EU to find out what languages are used by Estonian residents in informal and formal situations and environments (DfEE). In the context of globalisation, the topic of immigrants in Estonia and their educational needs, linguistic and cultural specificities have also gained more and more importance. Apart from that, attention must be paid to the skill of coping with the changed situation at the level of the society and the individual, while maintaining the immigrants' cultural identity and at the same time integrating them effectively into the Estonian cultural space. An important role in this is played by the education system. The Estonian public education curriculum (National curriculum for basic schools ..., 2010; National curriculum for upper secondary schools ..., 2010) promotes Estonian culture, common European values, multiculturalism and the cultural and scientific achievements of the world. The research at hand reflects Estonia's first experiences in that field. The research method used was unstructured in-depth interviews. The research results show that the state provides financial support for the education of new immigrant students, the school attempts to ensure a smooth adjustment of the students, although academic performance and the language level of the new immigrants are very different, the new immigrants generally cope linguistically and have mostly adjusted well, i.e. they have learned the Estonian language and have received peer and teacher support in the educational process. However, the instruction of the home language of the ethnic minority is left to the family.

Keywords: Estonian language, immigration, multicultural class, other languages, teaching methods.

\section{Introduction}

Only in the recent decade that considerable numbers of new immigrants started to arrive in Estonia; this has posed challenges to both the schools with Estonian language as their medium of instruction and those with Russian as their medium of instruction in Estonia, concerning how to cope with that new situation. For many children their home language is neither Estonian nor Russian, but the schools in Estonia mainly provide education in these two languages.

As in most cases the home language of a child having arrived in Estonia is different from the school's language of instruction, it is especially important that the teachers be flexible and that methods for differentiated learning be developed. Parallel to that, the financial means offered by the State for respective training of the teachers and for supporting the students' learning have also 
become a determining factor, so as to make their adaptation to the new linguistic and cultural environment as smooth as possible. The Estonian government provides sufficient support to the educating of new immigrant students in Tallinn Lilleküla Upper Secondary School being the focus of this research, but problems may occur (although not necessarily) in schools with fewer new immigrant students. The same goes for kindergartens in Estonia, having either Estonian or Russian as their study language. In that case, the State should have developed very specific and well-considered education policy decisions by that time. Amendments to legislation may also become necessary from time to time, if the laws adopted previously turn out to be outdated.

Tallinn Lilleküla Upper Secondary School is indeed the school with the highest numbers of new immigrant students in Estonia. The first new immigrant students started attending that school in 2003, and purely by chance, as it was simply the school of their place of residence back then. Over time, a tradition has developed that new immigrant students are preferably sent to attend the Tallinn Lilleküla Upper Secondary School, although there are such students in other schools, both in Tallinn and in other regions of Estonia.

The reasons why someone moves to another country are varied, be it temporarily or permanently, but whatever the reasons, the children always need fundamental protection and support as their socialisation would be hindered otherwise. Therefore, the conclusions of this research may be of interest to various countries upon making educational policy decisions concerning the adaptation of new immigrant students at schools. At the same time, it is interesting and useful to exchange experiences between countries, sharing one's own experiences and learning from those of others. Future plans include similar research with even more respondents, comparing the specificities across regions and possibly across countries as well.

\section{Theoretical background}

This research discusses communication in a multicultural classroom. For example, it can be claimed on the basis of earlier research (see, e.g., Linde, 1997) that the interpretation of communication between students coming from abroad and their local teachers can be very different for the parties involved, because they come 
from different cultural and linguistic environments. The addition of such transcultural aspects may enrich but may also hinder adaptation and learning of another language.

It is widely known that the school performs not only an educational but also socialising function (Küün, 2011). An important concept regarding the communication between various groups in a certain society is acculturation, which means the adoption of cultural elements when groups of people or nations with different cultural backgrounds meet (Viikberg, 1999, p. 18). For most children coming from abroad, educational institutions are indeed the main places where acculturation can occur (Vedder \& Horenczyk, 2006, p. 419). Therefore, students coming from abroad and students speaking Estonian as their native language should not be kept apart in schools - communication between them will help the newcomers adapt to the new linguistic environment, learn the destination country's language faster, will culturally enrich the children with Estonian as their native language, and, consequently, will enhance the acculturation as a result of the adaptation process (Rannut, 2005, p. 27).

Communication in the classroom can be challenging, especially for those students who are slower at learning new languages. The intercultural communication must be led by the teacher, so he or she has an important role in the classroom (Vedder \& Horenczyk, 2006; Kook, 2012). It can be presumed that as new immigrant students with different cultural backgrounds obtain a better command of the country's official language, they will start to communicate more frequently and more freely in the school and outside the school. Some children may use English as a lingua franca for quite a long period when communicating with each other; it does help with faster adaptation to the new environment but not with linguistic adaptation to the new country of residence because the national language of Estonia is, after all, Estonian.

In more than half the European countries, including Estonia, bilingual curricula are used in order to preserve the ethnic nationality or native language of children in regions where the linguistic environment does not support the development of their native language. Still, it is important for the State to continue establishing learning conditions for learning, to develop the curricula and to find teachers with the relevant training. In Estonia, additional Estonian lessons are provided to new immigrant students, so all newcomers initially learn Estonian 
separately from other students of their school. The time of the relevant study differs depending on the student; an individual approach is used in teaching the language.

The methods used for teaching children coming from abroad are important, but it can be assumed that a supportive classroom also helps the students adapt. It must be always kept in mind that the school must change its requirements and the learning environment so that the needs of its students are always met (DfEE, 1999). Naturally, not only the students' motivation but also their academic abilities have an important role in coping with the school requirements; yet this may also be influenced by their culture of origin. It has been found that where a child is encouraged to speak the language of his or her national minority, it is justified by the goal of the child's faster emotional and cognitive development (Goldenberg, Rueda \& August, 2006, p. 303; see also Küün, 2011, p. 226). Pursuant to the Basic Schools and Upper Secondary Schools Act in force in Estonia, $\S 21$ (5), a school is obligated to organise language and cultural teaching for students of national minorities if at least ten students with the same native language officially request it (Basic Schools and Upper Secondary Schools Act, 2008). Generally though, there are fewer than ten students of the same national minority in any given region of Estonia. This leads to the fact that teaching and maintaining the children's language and culture of origin remain solely the family's burden. Also, pursuant to the Basic Schools and Upper Secondary Schools Act in force in Estonia, $\S 27$ (1), a school is required to admit all persons subject to the duty to attend school who have expressed such a desire and for whom the school is the school of residence (Basic Schools and Upper Secondary Schools Act, 2008).

Having come to live in Estonia, parents can take their child to a school with Estonian or Russian as the language of instruction, but there are also other options available. There is the International School of Estonia in Tallinn, which uses an international curriculum in English; there is also Tartu International School in the second largest city of Estonia, which teaches basic school aged children mainly in English. Moreover, basic education can be obtained in Finnish in Tallinn Finnish School and in Tartu Finnish School. There are many so-called transit migrants in those schools, as their parents want to make sure that the children will obtain a competitive education and retain academic abilities in their 
native language (Kook, 2012). The parents who are unable to pay the tuition fee must take their children to other schools. The biggest problem of Estonian schools is currently the fact that they have relatively little experience of working with children arriving from abroad (Kook, 2012), as the situation of new immigrant students coming to live in Estonia has been relatively new for Estonia.

Still, trainings for teachers on how to work with new immigrant students are becoming more frequent in Estonia, preparing teachers for the challenges of working in a multicultural and multilanguage classroom. The Estonian state has also supported the issuance of the relevant learning materials for both children and adults. Naturally, the publication of new learning materials, the training of teachers and the development of curricula must require constant attention in the future as well.

\section{Methodology}

The research focuses on Tallinn Lilleküla Upper Secondary School as an example of students coming from abroad and Estonian students learning together, both in terms of learning the language first and foremost in the school environment and in terms of adapting to the learning activities related to that. In order to find out the specificities of learning and teaching and clarify the background related to the teaching of new immigrant students, the study was performed aimed at analysing the educational needs of some new immigrant students of Tallinn Lilleküla Upper Secondary School, as well as the opinion of the school's Head Teacher and a subject teacher on the difficulties faced, teaching strategies used and useful experience gained.

To achieve the research goal, the method of unstructured in-depth interviews was used, whereas spoken conversation was held with the respondents and their responses were also written down in parallel. The students were asked about their joys and worries, as well as about their support network. One part of the research was comprised of questions about the teaching strategies and methods of teachers. Participation in the research was voluntary and anonymous. Taking into account ethical considerationsm the parents had to provide a written consent allowing their child to participate in the research. It was necessary to visit the school two times (in April 2015). 


\section{Results}

The key person in organising the teaching of new immigrant students in Tallinn Lilleküla Upper Secondary School is the school's Head Teacher, being responsible for the curriculum, assigning language classes and, if necessary, co-ordinating the preparation of individual curricula then. She also conducts exams. The Head Teacher's responses help clarify the background of the relevant teaching in Tallinn Lilleküla Upper Secondary School.

The interview with the Head Teacher indicated that the new immigrants in Tallinn Lilleküla Upper Secondary School are taught according to the national curriculum. They also have individual curricula, which are followed while there is a need for that. The individual curricula foresee an intensive course of Estonian at first (ca. 6-10 hours per week); due to that, they cannot attend all subject lessons as they would exceed the maximum allowed load otherwise. According to the Head Teacher, the new immigrant students start to participate in all subject lessons gradually as soon as possible. She highlighted the subjects with the majority of difficulties as those where narration is needed (history, personal education, natural sciences and geography).

In the first academic year the students are taught Estonian as a second language (E2) for 8-10 hours per week. Estonian as a second language (E2) is taught for up to three years and language immersion is used as a study method. In later years, the number of language lessons gradually decreases, and the students start participating more in their main class subject lessons.

Head Teacher $(H)$ : If the language learning has progressed as planned, the student is ready to learn Estonian grammar and literature together with other students from then on. Individual characteristics are taken into account when teaching and assessing the students' language skills.

Thus, a markedly individual approach is applied to new immigrant students. It became apparent from the interview that Estonian legislation successfully promotes the studies of new immigrant students. In fact, the legislation has been amended (individual curricula, special requirements in standard-determining tests and exams) and the students can take their exams in 
their native language. Additionally, the state's financial means provided per student are larger in the case of new immigrant students, in order to be able to take the additional Estonian lessons. Teachers also have the opportunity to participate in training courses on new immigrant teaching, and the school teachers have participated in those. The Head Teacher is also satisfied with tours financed by the Estonian Ministry of Education and Research, taking new immigrants to various places in Estonia to become familiar with Estonia as a whole. Therefore, the extent of the State support can be considered sufficient, at least on the example of Tallinn Lilleküla Upper Secondary School.

Furthermore, the respondent also mentioned that due to the foreign linguistic and cultural environment, the new immigrant students are certainly in an emotionally difficult situation, but her opinion is that they largely cope well in the school. Tolerance is naturally required of all parties; immediate contact with differences stemming from cultural backgrounds is actually what increases the tolerance among Estonian children fastest, because they have a first-hand experience. There have been a few misunderstandings due to cultural differences in the school, but a compromise satisfying both parties has always been found fast.

As the students attend different classes, a schedule suitable for all of them is especially difficult to prepare. Moreover, the subject teachers miss the help of an assistant teacher - there was one working in the school, but not anymore, as the finances are insufficient for that now. This person supported the students in their learning after school, helped them do their homework and sometimes even accompanied them to classes. There is a distinct lack of assistant teachers currently felt at the school. Still, the student's class teacher carries some of the functions of a support teacher. Tutoring is available as special subject consultation classes, as well as during breaks.

According to the Head Teacher, the Estonian lessons are actually least problematic for the students. The interviewer was showed separate study rooms at school with a lot of additional language study materials gathered, which indicates that the teachers have done a great deal of work to make the learning diverse and exiting for the children.

For example, they have independently prepared small stage plays and rehearsed them with students, sometimes writing the scenarios on their own as 
well; also, illustrative materials are used a lot (e.g., videos and pictures), as well as materials intended for games. The Internet is also utilised to provide exciting interactive games for the students to develop their language skills. All language teachers can attest that language study by games is a pleasant and active experience for both children and adult learners. It provides a way to learn the language that is in some sense unnoticed by the learner - it can reduce the learning stress. In the first year, no grades are given to them (oral assessment is used); thereafter, their grades are given according to the system foreseen in the individual curriculum. Co-operation between the parents and the school is effective, although not always intensive. According to the respondent, the parents trust their school. Sometimes, meetings with parents are held, but the time of getting to know the students most comprehensively is when they first arrive at the school.

\section{H: Sometimes the co-operation is hampered by the language barrier.}

The interview indicated that some interesting events were organised in the course of studies, whereby some parents intend to participate in the studies as well, for example, to learn Estonian together with their child, or even to learn to ski together with their child in the physical education class. So the parents also have opportunities for active participation on varied levels. Tallinn Lilleküla Upper Secondary School has also arranged co-operation with other Estonian schools which teach new immigrants, and has had many visitors from other schools who intend to learn from Lilleküla School's study system for new immigrants. The Head Teacher interviewed is also a lecturer in that field.

The respondent was also asked whether other students are generally supportive of the new immigrants or whether there are also conflicts. The reply was: "They are generally supportive, above-average tolerant, but there have been some conflicts as well, just like between Estonian-speaking students." Apparently, the causes for such misunderstandings or conflicts have been neither the different cultural contexts nor the language barrier but rather general human differences between individuals. Moreover, new immigrant students as well as learners having lived in Estonia for a longer time are supported in taking the state exams: instead of the state exam of the Estonian language, new immigrant 
students can take an exam of Estonian as a second language or an exam prepared by the school. The mathematics exam can also be translated to the student's native language (provided there is a translator for the relevant language in Estonia). Exams are subject to the same special requirements as the individual curricula.

In order to find out the most complicated aspect of teaching for the new immigrant students - whether they encountered any linguistic or culture-related problems with other students, and what teaching strategies they used, the author interviewed the mathematics teacher $(M)$ of the same school.

\section{Teaching strategies of a subject teacher}

In order to find out the subject teacher's teaching strategies, the author had an interview with her, whereby it was revealed that upon working with the new immigrant students the mathematics teacher uses various teaching methods, including work with a dictionary in order to help the new immigrant students to adapt to the new situation. The use of dictionary helps her to speak the mother tongue of the new immigrant students, which enables them to get adjusted to new language of communication and new cultural environment more slightly.

M: For example, when teaching children who came from Italy, in the $5^{\text {th }}$ grade, the Estonian children learned the numbers in the Italian language and the new immigrants learned them in the Estonian language. The children control themselves. In addition, I used a word-image method.

The word-image method and, if necessary, the use of body language, is certainly justified in case of students who are newly arrived in the target country. In addition, this subject teacher has also used the method of peer teaching, when one student explains the subject material to other students.

M: When there were children speaking three different native languages in the class (French, Irish, Brazilian), I taught the smartest one. She, in turn, explained the subject forward to the other students. 
It is noteworthy that the teacher has involved the students themselves in explaining the educational material to others. It is a good educational experience for the student who explains the subject part to the classmates and also it has an educational impact on those with whom the peer deals with on an individual basis. This method could probably be used more in different schools in other subjects.

In teaching, the teacher combined the educational materials created by herself with the standard textbooks. Of course, this creates quite a lot of extra work for subject teachers; however, at the same time, the teacher tries to apply her own experience and creativity, which also leads to professional development of the teacher. The conversation revealed that the teacher occasionally added some English terms, as they were more familiar to the students. But in general, however, she taught mathematics in Estonian. The teacher of mathematics thought that actually mathematics as a subject would not create particular difficulties for the new immigrant students, because it is, after all, a relatively universal subject - especially if they came to live in Estonia at a time where kids are still going to the elementary school or in the first grades of the basic schools, as then mathematics is still fairly easy. She also mentioned that in the very beginning, part of the tasks can be solved even by means of images. Mathematics is one of the first subjects in which the students take part, coming to Estonia to learn in Estonian-language schools. The subject teacher said that, however, at the beginning of the study period, nothing is simple for the students and also emphasized the aspect of adaptation problems.

M: It is necessary to focus on a great number of things: a new country, a new language, new people, a new school and a new school system. Some, unfortunately, will never adapt.

Therefore, adaptation in a new language and culture environment proceeds smoothly not for all children. However, the fact that the child's support network is essential for adaptation should not be neglected - if his or her classmates, teachers of various subjects, the home class teacher, and the family, are supportive, adaptation is easier and faster. Of course, the student's own individual nature plays a significant role in the adaptation as well. 
Elvira KÜÜN

In her work this subject teacher has not encountered any possible problems arising due to the different cultural background. The respondent also briefly described how cooperation of the school and the parents operates: for the communication, the school and parents have jointly planned meetings as well as communication through the Internet, which helps to be well informed about the performance of the student, and to quickly intervene in case of any emerging problems.

The mathematics teacher said that the Estonian students want to interact with the new immigrant children namely in English, although the teachers follow the rule that they interact with everybody in the Estonian language from the very moment they have joined their subject class. Thus, owing to the new immigrant students, Estonian children are able to naturally improve their spoken English language skills in an authentic environment. However, this may create in the new immigrant students the habit of using the English language in communicating with the school, and it does not contribute to the development of their proficiency in Estonian - which is, after all, of the key importance to the Estonian school.

At the end of the interview the teacher of mathematics wanted to add that teaching new immigrants, however, is a challenge to the teacher because that must be done simultaneously while teaching the Estonian children. The teacher has to be able to simultaneously deal with everyone, regardless of different mother tongues, and to make every effort so that all the children in the class are able to acquire the content, at the same time, she has to prepare extra material for the class, using dictionaries and other reference sources and wisely combining the teaching methods.

\section{Adaptation and satisfaction of new immigrant children}

In order to find out the educational needs of Tallinn Lilleküla Upper Secondary School, children belonging to this category were also interviewed. For that, permissions were obtained from the parents of four children. The student respondents were R1, R2, R3 and R4. At that stage, the study focused on what creates the most difficulties for them in school and how they have overcome the difficulties, while it was also examined, what seems to be the easiest for them at school. All in all, it was investigated how, in their own opinion, the respondents 
cope when living in a new country and studying in a new school. The students were also asked about their friends and support network. It should be emphasized that participation in the interviews was anonymous and voluntary.

The interviewed students had come to Estonia to live from different countries and for various reasons: the source countries were Yemen, Russia, Sri Lanka and Iceland. Besides the respondent who came from Sri Lanka all the other respondents came to live in Estonia in 2013, the respondent from Sri Lanka, however, had arrived in 2010 and he had also attended an Estonian kindergarten for one year before school.

All children admitted having had difficulties in finding friends in the beginning when they took up residence in Estonia. One respondent explained that this was due to the fact that she could not speak either Estonian or English well enough to use the language for communication. However, one respondent also pointed out certain anxiety that came along with moving into a new environment.

All four students are taking part in the various interest groups, one of them goes in for volleyball training sessions, one attends fencing training sessions and one boy attends technical workshops to build aircraft models. One respondent (R1) also answered affirmatively but did not point out any specific interest group. Interest groups are certainly important in the formation of a child's personality and a positive self-image, provided that they offer the experience of success. Interest groups also help to socialize and find friends with similar interests among peers.

None of the students interviewed uses a specifically hired tutor, their help when doing homework is received from their Estonian mother or sisters. Only one respondent (R2) stated that he always does his homeworkat home alone, and pointed out that in the past he contacted a tutor for support, but now he has no need for support any more.

Students were also asked about their biggest challenges at school, and they indicated all kinds of problems - some issues of concern were related to subjects ("dislikes physical education"), and some were related to misunderstandings emerged at the school. Respondents R3 and R1 said that they had no concerns associated with the school. Indeed, there are students at schools for whom physical education is a favorite subject, but there are those who do not like this at all - it may be due to a low fitness level, which may, in some cases, 
even cause a fear of that subject. This situation can be improved by starting training physically on one's own because, in addition to physical fitness, sport develops self-confidence. From another respondent's responses it can be deducted that relations with some fellow students are not the best. As it turned out, however, from the conversation with the Deputy Headmaster, there are occasional conflicts both between new immigrant students and the Estonian students as well as among the Estonian children themselves. Apparently, this is the way how the group relations are figured out, especially in the initial period of the arrival of a new student. However, according to the Deputy Headmaster, the students of their school are even more tolerant than the average, and, in general, there are no conflicts.

The students were also asked about what brings them the most joy at school. One of the things pointed out was the help of others (for example, the same boy who had previously mentioned misunderstandings with schoolmates), as well as friends who help the new immigrant students to adapt faster. Several respondents emphasized that for them the biggest joy is caused by spending time with friends - and not only in school but also the free time after the lessons. Without exception, all indicated that they have friends among Estonians, which indicates the existence of a support network. The student respondents also talked about the easiest subjects for them and gave reasons why these subjects seemed to be the easiest for them.

\section{R1: Estonian as a second language (E2).}

As a reason the respondent $\mathrm{R} 1$ added that the E2 subject is the easiest for her because she studies it a lot, that is why it does not seem so difficult anymore. Another respondent (R2), however, added another reason:

\section{R2: I like the fact that the Estonian language sounds nice.}

For the third child mathematics was the easiest subject. He said that he had liked this subject from the 1st grade, because it is a simple subject. The fourth respondent had the widest range of interests as he pointed out that for him 
one of the easiest subjects was Estonian as a second language, as well as a few more.

R4: Estonian as a second language, robotics, art, boys' crafts, physical education.

As a reason, he added that in these classes it is possible to understand the tasks fast. As can be seen, this reasoning can be seen as a clear link with the Estonian language skills.

As one of the objectives of the study was to investigate the way the new immigrant students cope in a school with the Estonian as a language of instruction, they were also asked about the most challenging subjects. The answers were various.

\section{R1: English is difficult.}

R2: Physical education is the most difficult for me.

R3: The Estonian language as a first language.

R4: History, the Estonian language as a first language, nature study.

The students explained their answers as follows: "Estonian and English distract each other - I keep mixing them up with each other occasionally" (R1), "I do not like sports" (R2), "Sometimes, I don't know some words, then I ask the teacher" (R3), "Because I do not understand." (R4). It can be seen that in a number of cases, the difficulties arise precisely within the so-called narrative subjects, because the Estonian language learning is, after all, still in progress, and therefore the language level in the language of instruction, in some cases is not yet sufficient to understand the entire subject material. However, language proficiency is gradually improving, and the content of the narrative subjects should become easier. Gradually the horizon is also expanding, and better connections may begin to emerge between the subjects as well as within a subject. Generally the skill subjects, where one can also learn by way of demonstration, were considered to be easier subjects; there the language skills are not so crucial for understanding.

When inquiring the respondents on whether they are able to learn their language and culture of origin outside the home, such as in the Sunday school, 
Elvira KÜÜN

the response was obtained from all that they do not have this option. Consequently, promotion and development of the home culture and language has been left fully in the care of the family. It is unfortunate, therefore, that there is a real risk that the literacy in the corresponding language remains in the background, and possibly even neglected, because in the home environment, the language of their country of origin is used after all, only orally. For example, respondent R4 pointed out, however, that over time, he has begun to reveal a tendency to forget the Icelandic language to some extent.

At the same time, it was mentioned that newspapers, magazines, and books are still read in the language of their country of origin, e.g., over the Internet. However, students prefer to read the media on the Internet as well as in hard copy mostly in the Estonian language. Only respondent R4 pointed out that, in addition to the Estonian language, she often uses the English language when reading. It was also mentioned that sometimes they read in the classroom, where they also read magazines and newspapers. In the opinion the author of this study, it is a useful method to study Estonian, (or English or any other language) since such materials are authentic texts.

It was also interesting to learn in which language TV shows are watched and which channels or programs are interesting for the interviewed new immigrant students. Both Estonian and English-language television channels and different genres of television programs (cartoons, various children's programs and action movies) were mentioned.

The interviews were conducted with students in the Estonian language, only a little English was required, but they were also given the opportunity to respond in their native language (they did not use this possibility). However, it should be stressed that the measurement of language skills was not a separate object - therefore, the aspects of language skills are simply mentioned here as the language skills have a large role in coping in the school and elsewhere in linguistic environments.

\section{Conclusions}

The results of this work show that in the Estonian educational system, the state provides financial support for the education of new immigrant students, i.e., the 
students who have been in Estonia for less than three years. Tallinn Lilleküla Upper Secondary School has many new immigrants enrolled in the school - that is the reason why the school has sufficient finances to teach them the Estonian language additionally. However, it may happen that if the school had fewer new immigrants, the fee targeted to new immigrants would not be adequate anymore.

Generally, the instruction of the home language of the ethnic minority is left to the family, because often there will not be a minimum of ten students of the same mother tongue in the same area. In the school, however, there are possibilities for students to compare cultural issues such as which holidays are held in the country of origin of the new immigrant and how their habits and traditions are different from the Estonian folk traditions. It is an enriching experience for both the teacher and the Estonian children as well as for the new immigrants themselves.

The results also show that the school attempts to ensure a smooth adjustment of the students who came from abroad: new immigrants have shorter school days and they are not graded in the first academic year. New immigrants also have a different curriculum - in the beginning, they attend separate language classes. In addition to language lessons, at the outset, the newly arrived immigrants attend the classes of skill subjects and mathematics. Only as the language skills develop, they increasingly participate in other subject classes.

The analysis shows that although the language level of the new immigrants enrolled in Tallinn Lilleküla Upper Secondary School is very different, still, a general trend can be brought out - namely, according to the Deputy Headmaster, the new immigrants generally cope linguistically satisfactorily in the school, and the students arrived from abroad, who have been in Estonia for more than three years, have mostly adjusted well. They have learned the Estonian language and are coping with the educational process. It can, therefore, be assumed that the methods used by the school justify themselves. The methods used with new immigrants are pair and group work, gestures and facial expressions are also used, especially at the beginning, as well as duplication of activities (simultaneous speaking and writing), demonstration, interactive exercises, games and computers, in addition, a lot of supplementary worksheets are used along with the textbooks. In the classrooms, newspapers and magazines are freely available; moreover, for the subconscious acquisition of the language 
"talking walls" are used, where the most common grammar and sentence structures are placed on the walls. The teaching integrates nonverbal and verbal strategies.

The results show that the academic performance of the children who arrived from a foreign country is different. The time of resettlement in Estonia plays an important role, i.e., generally those new immigrants arriving in another country at later ages have a harder time performing well academically, as they are also required to learn the narrative subjects, which are difficult due to their low language proficiency. Besides, the students' learning habits and the curriculum established by the school are also important. According to the Deputy Headmaster, students are able to cope at school, definitely at least at a satisfactory level. Some of them are opted to go to subject competitions, and they have successfully represented the school there.

Generally, parents cooperate with the school; whenever possible, they take part in various school events. The results show that the support that the students who have come from abroad receive mainly comes from their friends, who have been of assistance in terms of acquisition of both the language and other subjects. Some students, however, also stress that they have also received additional assistance from their teachers. All respondents appeared to have quite a strong social network - they have found new friends who support them, if necessary, both at school and outside of school.

While teaching new immigrants, it is necessary to have a reasonable attitude and patience, at the same time, of course, additional work needs to be done, for example, additional tasks have to be created and sometimes translations need to be performed. For some children it is difficult to adapt to an unfamiliar cultural space in a new school. Apparently a person's temperament plays a role in adaptation. Most important, of course, is that children experience success in the class and feel emotionally safe in the lessons. Generally, it should be a subject teacher who should give the first indication whether the child has difficulties in studies and if the curriculum needs to be reduced. In this case, the child's individual curriculum will be reviewed and, where possible, for example, the number of language lessons will be increased. In summary, it can be argued that in Tallinn Lilleküla Upper Secondary School adequate opportunities have been created for learning and adaptation of children who have arrived from abroad. 
Finally, the limitations of the study should be presented. It is evident that on the basis of only six interviews it is possible to present a sketch of linguistic adaptation of new immigrants at a particular school rather than make broad generalizations on the linguistic adaptation of the students that have arrived from abroad in Estonian schools in general. Therefore, this topic requires a more indepth approach in the further investigation and the studies with more respondents, for example, in various regions in Estonia and other countries. However, the results obtained in this study are a good example for the collection of information on the children who arrived from abroad.

\section{References}

Basic Schools and Upper Secondary Schools Act. (2008). Riigi Teataja I, 41, 240. Retrieved from https://www.riigiteataja.ee/akt/968165 (sited $18^{\text {th }}$ October 2014).

DfEE. (1999). The National Curriculum Key Stages 1 and 2. DfEE and QCA: London.

Goldenberg, C., Rueda, R. S., \& August, D. (2006). Sociocultural influences on the literacy development. In D. August and T. Shanahan (Eds.) Developing Literacy in Second-language Learners. Report of the National Literacy Panel on Language-Minority Children and Youth (U.S.), National Center for Applied Linguistic, 2, 123-134.

Helemäe, L., Plotkin, A., Semjonov, A., \& Vöörmann R. (2000). Identiteedi kujunemise probleemid post-sotsialistlikus keskkonnas. [Identity formation problems in post-socialist environment.] Tallinn 1999-2000. Tallinn: Inimõiguste Teabekeskus.

Kook, M. (2012). Välismaalt tulnud õpilaste keeleline kohanemine Tallinna Lilleküla Gümnaasiumi näitel. [Bakalaureusetöö.] [Foreign-language adaptation of students coming from abroad in Tallinn Lilleküla Upper Secondary School as an example. Bachelor thesis.] Tartu University.

Küün, E. (2011). Minority languages in Estonian segregative language environments. Journal of Estonian and Finno-Ugric Linguistics. Tartu University, 223-241. 
Elvira KÜÜN

Linde, C. (1997). Intercultural communication within multicultural schools: educational management insights. Education, 118(2), 191-205.

Moon, B., \& Ben-Peretz, M., \& Brown, S. (Eds.) (2000). The Routledge Companion to Education. London, New York: Routledge.

National curriculum for basic schools (2010). Retrieved from https://www.riigiteataja.ee/. (Sited 15 th December 2014).

National curriculum for upper secondary schools (2010). Retrieved from https://www.riigiteataja.ee/. (Sited 15th December 2014).

Rannut, Ü. (2005). Keelekeskkonna mõju vene õpilaste eesti keele omandamisele ja integratsioonile Eestis. [Language environmental impact of the acquisition of the Estonian language, and Russian students integration in Estonia.] Tallinn: Tallinn University Press.

Vedder, P. H., \& Horenczyk, G. (2006). Acculturation and the school. In D. L. Sam (Ed.) The Cambridge Handbook of Acculturation Psychology, 43, 419438.

Viikberg, J. (1999). Eesti rahvaste raamat. [Book of Estonian Nations.] Tallinn: Eesti Entsüklopeedia.

\section{Elvira Küün}

Narva Colledge of Tartu University, Estonia

Elvira.Kuun@ut.ee

\section{UUSSISSERÄNDAJATEST ÕPILASTE ÕPPIMISE JA ÕPETAMISE ISEÄRASUSED EESTI KOOLI NÄITEL}

Kokkuvõte. Käesoleva artikli aluseks olnud uuringu tulemustest nähtub, et Eesti haridussüsteemis pole välismaalt saabunud õpilaste õpetamiseks välja töötatud eraldi õppeprogrammi. Välismaalt saabunud õpilased, kes on Eestis elanud üle kolme aasta, õpivad riikliku õppekava järgi, eesti keelt õpitakse õppeprogrammi järgi teise keelena. Õpilastele koostatakse individuaalne õppekava. Riik toetab rahaliste ressurssidega uusimmigrantõpilaste õpet ehk õpilasi, kes on Eestis olnud vähem kui kolm aastat. Riik maksab õpetamise eest koolile omavalitsuste kaudu iga õpilase kohta teatud summa tema koolitamise eest, mis on suurem kui tavalise õpilase n-ö pearaha, ja selle arvelt on ette nähtud eesti keele õpetamine. Täiendavat keelelist tuge pakutakse ka põhikooli Iõpetamisel - uusimmigrantide üheksanda klassi Iõpueksamid tõlgitakse vajadusel õpilase emakeelde.

Riigi toetusega ollakse uuritud õppeasutuses üldjoontes rahul. Seda seepärast, et vastavas koolis õpib suhteliselt palju uussisserännanuid - seega on koolil piisavalt raha, et neile eesti keelt õpetada. Samas juhul kui seal õpiks vähem uusimmigrante, siis ei oleks neile mõeldud pearaha ilmselt piisav. Näiteks Eestis töötavad vene õppekeelega koolid aga ei saa eraldi n-ö pearaha juurde, kuna neil on juba niigi olemas eesti keele kümblusprogrammid. 
Tulemustest selgus, et antud koolis on uusimmigrantidel lühemad koolipäevad ja nende õpitulemusi esimesel õppeaastal ei hinnata. Uusimmigrandid õpivad veidi kohandatud tunniplaani järgi, kusjuures õppetöö alguses käiakse eraldi keeletundides. See täidab samuti uussisserännanute kiirema kohanemise eesmärki. Lisaks keeleõppetundidele käivad uusimmigrandid paralleelselt ka oskusainete tundides ja õpivad matemaatikat. Sedamööda, kuidas keeleoskus areneb, hakatakse üha rohkem muudes ainetundides osalema.

Üldiselt selgus tulemustest tendents, et uuritud koolis saavad uusimmigrandid üldjuhul hästi või vähemalt rahuldaval tasemel hakkama, kuigi õppeedukuses ja keeleoskuses võib leida indiviiditi üsnagi suuri lahknevusi - see sõltub muu hulgas ka sellest, millise taustaga õpilane on. Selle all on silmas peetud eelkõige seda, milline on lapse päritolukultuur - seda seetõttu, et lapse õppimisharjumused on siiski seotud ka tema kultuurilise taustaga. Kahtlemata mängivad õppeedukuses lisaks suurt rolli õpilaste vaimsed võimed, vähem tähtis pole ka õppekava sobivus. Vastava kooli intervjueeritud õppejuhataja sõnul aga on osa õpilastest soovinud isegi aineolümpiaadile minna ja nad on seal edukalt kooli esindanud. Üldiselt on kohanemise korral oluline faktor lapse vanus sel ajal, kui ta on teise riiki elama asunud. Üldjuhul kaldub õppetöös raskem olema neil uusimmigrantidel, kes tulevad sihtriigi kooli vanemas eas, sest peavad osalema hakkama ka n-ö jutustavates ainetes (nt ajalugu ja loodusõpetus), mis aga on vähese keeleoskuse tõttu alguses raske: ainesõnavara on lai ja seetõttu on seda keeruline meelde jätta. Mõne uusimmigrantõpilase jaoks on ka koolis kohanemine raske. Kõigil lastel ei ole võõras kultuuriruumis ja uues koolis kerge adapteeruda. IImselt mängib selle juures rolli ka inimese temperament, kuid mingil määral on uus keskkond stressiallikas siiski ilmselt kõigi uussisserännanute jaoks.

Kõige vähem on uusimmigrantõpilastel abi vaja läinud oskusainetes. Mainiti ka matemaatikat, sest numbrid on universaalsed. Seega on uusimmigrantidel raskem jutustavates õppeainetes, kuid neile tundub lihtsam õppida oskusaineid, matemaatikat, eesti keelt teise keelena ja sageli ka inglise keelt. Kõige tähtsam on see, et lapsed saavad tunnis eduelamuse ning tunnevad endid ainetundides mugavalt ja emotsionaalselt turvaliselt. Üldiselt peaks just aineõpetaja esimesena märkama seda, kui lapsel on õppetöös raskused. Sel juhul tuleks individuaalset õppekava muuta, suurendades nt keeletundide mahtu.

Käesoleva artikli aluseks olnud uuringu tulemustest selgus, et õpetamisel kasutatakse erinevaid meetodeid, nagu näiteks paaris- ja rühmatöö, näitlikustamine, tegevuse dubleerimine, palju tarvitatakse ka töölehti ning interaktiivseid ülesandeid, samuti kehakeelt ning žeste. Eri aktiivõppemeetodeid kasutavad õpetajad keeleõppes sageli ning katsetavad samuti uusimaid võimalusi selles vallas. Selgus ka asjaolu, et interaktiivsete mängude ning arvuti ja interneti kasutamine meeldib lastele üha enam, seega on soovitatav kasutada tunni huvitavaks muutmisel lisaks tavapärasematele vahenditele ka neid meetodeid. Lisaks võiks proovida katsetada ka ühe keeleõppe meetodina "rääkivaid seinu", kus on seintele paigutatud levinumad lausekonstruktsioonid ja väljendid (nt sööklasse üldised viisakusväljendid ja eraldi aineruumidesse vastavat õppeainet puudutav sõnavara). Muidugi tuleks ka jätta riiulitele sirvimiseks või lugemiseks ajakirju jms, mida õpilased võivad vahetunnis (või aeg-ajalt ka tunnis) soovi korral kasutada. Kõiki neid võimalusi ja palju muidki õpetajad uuritud koolis ka kasutavad. Tundi lisab elevust ning toetab ühtlasi keeleõppe arengut kindlasti ka see, kui tunnis aeg-ajalt võrreldakse, mis pühi peetakse uusimmigrandi päritolumaal ja mille poolest nende tavad ja kombed eesti rahvalikest traditsioonidest erinevad. Rikastav kogemus on see nii õpetajale, eesti lastele kui ka uusimmigrandile endale.

Leidis kinnitust ka asjaolu, et sõltuvalt situatsioonist võib keelevalik erineda. Kui koolis ja igapäevastes situatsioonides kasutatakse nii eesti kui ka inglise keelt (teatud juhtudel ka vene keelt), siis kodus räägivad kõik oma emakeeles. Seda tõenäoliselt seetõttu, et vanemad ei oska eesti keelt (juhul kui muidugi üks vanematest ei ole eestlane). Samal ajal pakutakse ka täiskasvanud uusimmigrantidele Eestis suhteliselt piisaval hulgal tasuta keelekursuseid keeleõppe firmade kaudu. Üldiselt teevad lapsevanemad kooliga koostööd, lisaks võtavad võimaluse korral osa ka laste pidudest ja erinevatest kooliüritustest.

Kokkuvõttes võib väita, et Tallinna Lilleküla Gümnaasiumis on loodud piisav hulk võimalusi uussisserännanute laste õppeks ja adapteerumiseks ning selle kooli 
õppestrateegiad võiksid olla selles vallas teistelegi koolidele eduka näitena eeskujuks. Kuigi käesoleva artikli aluseks olevas uuringus oli intervjueerituid suhteliselt vähe, on saadud tulemused siiski hea näide välismaalt saabunud laste kohta informatsiooni kogumisel, süvaintervjuud andsid selleks hea võimaluse. Lõppeesmärgiks oleks aga tulevikus asetada Eestis tehtud vastavad uurimused rahvusvahelisse konteksti.

Võtmesõnad: eesti keel, immigratsioon, mitmekultuuriline klass, õpetamismeetodid, teised keeled.

\section{Elvira Küün}

Tartu universiteto Narvos kolegija, Estija

Elvira.Kuun@ut.ee

\section{NAUJUJU IMIGRANTU MOKSLEIVIY MOKYMO IR MOKYMOSI YPATUMAI: ESTIJOS ATVEJIS}

Santrauka. Jau nuo 2004 metu Estija yra Europos Sajungos narè, todèl labai svarbu išsiaiškinti, kokias kalbas Estijos, kaip ES šalies narès gyventojai, vartoja formaliose ir neformaliose situacijose bei aplinkose. Globalizacijos kontekste tokios temos, kaip imigrantu situacija Estijoje, t. y. ju švietimo poreikiai, lingvistinis ir kultūrinis specifiškumas tampa vis svarbesnès. Be to reikia atkreipti dèmesi i gebejjima susidoroti su pasikitusia situacija visuomenès ir individo lygmenyje, išlaikant imigrantu kultūrini tapatuma ir tuo pat metu efektyviai integruojantis i Estijos kultūros erdvę. Šioje situacijoje Estijos švietimo sistema atlieka svarbu vaidmeni. Estijos valstybine švietimo programa (Nacionalinè programa pagrindinèms mokykloms, 2010; Nacionalinè programa vidurinèms mokykloms, 2010) skatina Estijos kultūros plètojima, bendruju europiniu vertybiu puoseléjima, daugiakultūriškuma bei susipažinima su pasaulio kultūros ir mokslo pasiekimais. Šiame tyrime pristatome pirminę Estijos patirti. Tyrimo metodas - nestruktūruotas giluminis interviu su mokytojais ir mokiniais. Tyrimo rezultatai parodè, kad valstybè teikia finansinę parama atvykusiu besimokančiu imigrantu integracijai, mokykla siekia užtikrinti sklandžia mokiniu adaptacija. Nors nauju imigrantu akademinis pasirengimas ir kalbos lygis labai skiriasi, bet nauji imigrantai geba susidoroti su lingvistiniais sunkumais ir prisitaiko gan gerai, t. y. išmoksta estu kalba ir švietimo procese sulaukia bendraamžiu bei mokytoju paramos. Vis dèlto etniniu mažumu namu kalbos mokymas/is paliktas šeimos atsakomybei.

Pagrindinès sąvokos: daugiakultūrè klasè, estu kalba, imigracija, kitos kalbos, mokymo metodai. 